\title{
VIEWPOINT
}

\section{Low-Dose Computed Tomographic Screening for Lung Cancer: Time to Implement or Unresolved Questions?}

\author{
Aakash Desai, MBBS, $M P H^{7}$ and Vinay Prasad, $M D, M P H^{2,3}$
}

'Department of Internal Medicine, University of Connecticut, Farmington, CT, USA; ${ }^{2}$ Department of Medicine, University of California, San Francisco, San Francisco, CA, USA; ${ }^{3}$ Department of Epidemiology and Biostatistics, University of California, San Francisco, San Francisco, CA, USA.

$\mathrm{J}$ Gen Intern Med 36(10):3202-4

DOI: $10.1007 / \mathrm{s} 11606-021-06806-5$

(c) Society of General Internal Medicine 2021

$\mathrm{L}$ ung cancer results in more cancer deaths than breast, prostate, colorectal, and brain cancers. Since most lung cancer patients are identified at advanced stages, with a 5-year survival of $<15 \%$, the prospect of screening has garnered much attention. Yet, early results were disappointing. Trials investigating the utility of chest radiography (CXR) and sputum cytology for screening failed to demonstrate a mortality benefit. However, more recent studies assessing low-dose computed tomography (LDCT) have yielded promising results, spurring enthusiasm. These trials also have quantified the magnitude of potential benefit, but also suggest continued unresolved questions.

In 2011, the National Lung Screening Trial (NLST) ${ }^{1}$ demonstrated a $20 \%(95 \% \mathrm{CI}, 6.8$ to $26.7 ; P=0.004)$ relative reduction in mortality from lung cancer, as well as improved all-cause mortality by $6.7 \%(95 \% \mathrm{CI}, 1.2$ to $13.6 ; P=0.02)$ with LDCT over CXR. Concerns were raised however that the trials' non-standard control arm may mask potential harms, as well as the fact that the significance of overall mortality in the initial publication was contingent on a numerical imbalance in non-lung cancer deaths. In other words, a difference in nonlung cancer deaths that happened to favor the CT screening arm was necessary for the NSLT to have an overall mortality benefit. For this reason, it is not surprising that in an extended follow-up, the overall mortality benefit is no longer significant $^{2}$ (RR 0.97 (95\% CI: 0.94-1.01); the difference in the number dying (per 1000) is 4.2 (95\% CI: -2.6 to $10.9, p$ $=0.18$ ). Despite these caveats, the United States Preventive Service Task Force (USPSTF) and Canadian Task Force on Preventive Health Care endorsed annual screening LDCT for lung cancer in adults aged 55 to 80 years with a 30 pack-year smoking history who currently smoke or have quit within the past 15 years.

Received November 17, 2020

Accepted April 3, 2021

Published online April 26, 2021
Additional evidence from trials like DANTE, ITALUNG, and LUSI (Table 1) failed to demonstrate a significant lung cancer mortality benefit with LDCT. Additionally, no allcause mortality benefit was seen among the screening cohorts. Against this backdrop, the recent publication of the NELSON trial was keenly anticipated.

NELSON $^{6}$ compared a strategy of four annual screenings with LDCT to no screening among male smokers 50-74 years old, with $>15$ cigarettes a day for $>25$ years or $>10$ cigarettes a day for $>30$ years and have quit less than 10 years ago. The average number of screening CT scans in the intervention arm was 3.43. At a median follow-up of 10 years, NELSON found that lung cancer mortality was significantly lower among atrisk individuals who underwent LDCT compared with no screening among high-risk patients $(2.43 \%$ vs $3.17 \%)$.

At the same time, NELSON raises important concerns. Lung cancer mortality requires adjudication, and attribution of death is not an exact science. ${ }^{7}$ An endpoint less prone to interpretation is death from any cancer. In NELSON, this endpoint occurred in 499 of $6612(7.54 \%)$ control arm participants and 478 of $6583(7.26 \%)$ intervention arm participants, a difference that fails to meet nominal significance.

All-cause mortality is resistant to observer interpretations, and here too NELSON provides a cautionary note. Despite the $0.74 \%$ reduction in lung cancer death, no difference was seen in all-cause mortality between the two groups $(13.76 \%$ (control) vs $13.93 \%$ (screened)) [RR: 1.01 (0.92-1.11)]. Although not powered to assess all-cause mortality, the numerical difference in lung cancer death was not preserved in the all-cause mortality statistic. This result has been observed in other cancer screening trials such as the Minnesota Colon Cancer Control Study. ${ }^{8}$ It is important to clarify what this result means. A common misconception is that all-cause mortality is unchanged in cancer screening trials because death is inevitable. While it is true we all die, NELSON suggests that when approximately one in 7 individuals has experienced the event of interest, there was no suggestion death is delayed in the screening arm. At the same time, the study lacks power to render a final verdict on this outcome, so residual uncertainty is present.

One notable comparison between the NELSON trial and the NLST is the markedly reduced rate of a positive screening LDCT result in NELSON (2.1\% vs $24.2 \%$ ). This may be explained by what the trials considered as "positive." The 
Table 1 Clinical Trials for Lung Cancer Screening with LDCT

\begin{tabular}{|c|c|c|c|c|c|c|c|}
\hline $\begin{array}{l}\text { Clinical trial } \\
\text { (year), coun- } \\
\text { try }\end{array}$ & $\begin{array}{l}\text { Comparison/control } \\
\text { group }\end{array}$ & $\begin{array}{l}\text { Eligible } \\
\text { subjects }\end{array}$ & $\begin{array}{l}\text { Rate of } \\
\text { adherence }\end{array}$ & $\begin{array}{l}\text { Rate of } \\
\text { positive } \\
\text { screening } \\
\text { LDCT }\end{array}$ & $\begin{array}{l}\text { Lung cancer } \\
\text { incidence }\end{array}$ & $\begin{array}{l}\text { Lung cancer } \\
\text { mortality }\end{array}$ & $\begin{array}{l}\text { All-cause } \\
\text { mortality }\end{array}$ \\
\hline $\begin{array}{l}\text { NLST } \\
(2011),{ }^{1} \\
\text { United States }\end{array}$ & $\begin{array}{l}3 \text { annual screenings } \\
\text { with LDCT vs } \\
\text { single-view } \\
\text { posteroanterior chest } \\
\text { radiography }\end{array}$ & $\begin{array}{l}\text { I. } 55-74 \text { years } \\
\text { II. Male or } \\
\text { female } \\
\text { III. } 30 \\
\text { pack-years } \\
\text { IV. Quit within } \\
15 \text { years }\end{array}$ & $>90 \%$ & $24.2 \%$ & $\begin{array}{l}645 \text { vs } 572 \text { (per } \\
100,000 \text { person- } \\
\text { years) (RR: } 1.13 \\
[1.03-1.23])\end{array}$ & $\begin{array}{l}247 \text { vs } 309 \\
\text { (RRR: } 20 \% \\
{[6.8 \text { to } 26.7]} \\
p=0.004)\end{array}$ & $\begin{array}{l}6.7 \%(95 \% \mathrm{CI} \\
1.2 \text { to } 13.6 ; p= \\
0.02)\end{array}$ \\
\hline $\begin{array}{l}\text { DANTE } \\
(2015),{ }^{3} \text { Italy }\end{array}$ & $\begin{array}{l}4 \text { annual screenings } \\
\text { with LDCT vs no } \\
\text { screening }\end{array}$ & $\begin{array}{l}\text { I. } 60-74 \text { years } \\
\text { old } \\
\text { II. Male } \\
\text { smokers or } \\
\text { former smokers } \\
\text { III. } 20 \\
\text { pack-years } \\
\text { IV. Quit less } \\
\text { than } 10 \text { years }\end{array}$ & $\mathrm{N} / \mathrm{A}$ & $37 \%$ & $\begin{array}{l}8.23 \% \text { vs } 6.07 \% \\
(p=-.0418)\end{array}$ & $\begin{array}{l}543 \text { vs } 544 \\
\text { (HR: } 0.993 ; \\
95 \% \text { CI, } \\
0.688-1.433 \text { ) } \\
\text { [Not } \\
\text { significant] }\end{array}$ & $\begin{array}{l}1655 \text { vs } 1742 \\
\text { per } 100,000 \\
\text { person-years } \\
\text { (HR: } 0.947 ; 95 \% \\
\text { CI, } 0.769-1.165 \text { ) } \\
\text { [Not Significant] }\end{array}$ \\
\hline $\begin{array}{l}\text { ITALUNG } \\
(2017),{ }^{4} \text { Italy }\end{array}$ & $\begin{array}{l}4 \text { annual screenings } \\
\text { with LDCT vs no } \\
\text { screening }\end{array}$ & $\begin{array}{l}\text { I. } 55-69 \text { years } \\
\text { old } \\
\text { II. Male or } \\
\text { female } \\
\text { III. } 20 \\
\text { pack-years } \\
\text { IV. Quit less } \\
\text { than } 10 \text { years }\end{array}$ & $81 \%$ & $\mathrm{~N} / \mathrm{A}$ & $\begin{array}{l}67 \text { vs } 71 \\
((\mathrm{RR})=0.93 ; 95 \% \\
\text { CI } 0.67 \text { to } 1.30)\end{array}$ & $\begin{array}{l}30 \% \text { reduction } \\
(\mathrm{RR}=0.70 ; \\
95 \% \text { CI } 0.47 \text { to } \\
1.03) \\
{[\text { Not }} \\
\text { significant] }\end{array}$ & $\begin{array}{l}17 \% \text { reduction } \\
(\mathrm{RR}=0.83 ; 95 \% \\
\text { CI } 0.67 \text { to } 1.03) \\
\text { [Not significant] }\end{array}$ \\
\hline $\begin{array}{l}\text { LUSI } \\
(2019),,^{5} \text { Ger- } \\
\text { many }\end{array}$ & $\begin{array}{l}5 \text { annual screenings } \\
\text { with LDCT vs no } \\
\text { screening }\end{array}$ & $\begin{array}{l}\text { I. } 50-69 \text { years } \\
\text { old } \\
\text { II. Male or } \\
\text { female } \\
\text { III. }>15 \\
\text { cigarettes a day } \\
\text { for }>25 \text { years or } \\
>10 \text { cigarettes a } \\
\text { day for }>30 \\
\text { years } \\
\text { IV. Quit less } \\
\text { than } 10 \text { years }\end{array}$ & $>90 \%$ & $4-22 \%$ & $\begin{array}{l}85 \text { vs } 67 \\
(p=0.16)\end{array}$ & $\begin{array}{l}\text { HR: } 0.74(95 \% \\
\text { CI: } 0.46-1.19 ; \\
p=0.21) \\
{[\text { Not }} \\
\text { significant] }\end{array}$ & $\begin{array}{l}\text { HR }=0.99[95 \% \\
\text { CI: } 0.79-1.25], p \\
=0.95 \\
\text { [Not significant] }\end{array}$ \\
\hline $\begin{array}{l}\text { NELSON } \\
(2020),{ }^{6} \\
\text { Netherlands }\end{array}$ & $\begin{array}{l}4 \text { annual screenings } \\
\text { with LDCT vs no } \\
\text { screening }\end{array}$ & $\begin{array}{l}\text { I. } 50-74 \text { years } \\
\text { old } \\
\text { II. Male } \\
\text { III. }>15 \\
\text { cigarettes a day } \\
\text { for }>25 \text { years or } \\
>10 \text { cigarettes a } \\
\text { day for }>30 \\
\text { years } \\
\text { IV. Quit less } \\
\text { than } 10 \text { years }\end{array}$ & $90 \%$ & $2.1 \%$ & $\begin{array}{l}5.58 \text { vs } 4.91 \\
\text { cases per } 1000 \\
\text { person-years }\end{array}$ & $\begin{array}{l}2.50 \text { deaths vs } \\
3.30 \text { deaths per } \\
1000 \text { person- } \\
\text { years } \\
\text { CR: } 0.76(\mathrm{M}) \\
(0.61 \text { to } 0.94 ; P \\
=0.01)\end{array}$ & $\begin{array}{l}13.93 \text { vs } 13.76 \\
\text { deaths per } 1000 \\
\text { person-years, } \\
\text { RR: } 1.01(0.92- \\
1.11)\end{array}$ \\
\hline
\end{tabular}

NLST defined LDCT's with any non-calcified nodule measuring at least $4 \mathrm{~mm}$ in any diameter as well as radiographic images that revealed any non-calcified nodule or mass as positive. Meanwhile, NELSON classified a non-calcified nodule into 4 different categories based on size or growth pattern. The trial protocol defined nodule category (NODCAT) category IV lesions [solid $>500 \mathrm{~mm},{ }^{6}$ partial solid with solid component $>500 \mathrm{~mm}^{6}$ and solid, pleural based $>10 \mathrm{~mm} \mathrm{dmin}$ ] and growth category (GROWCAT) $\mathrm{C}$ lesions to be identified as "positive." In NELSON, another 2069 scans (9.2\%) were inconclusive. Thus, the difference in positive screen results may in part be explained by nomenclature.

Finally, the harms of screening with LDCT, mainly the false positive rates and their attendant downstream effects, must be considered. CT screening can lead to multiple diagnostic follow-up procedures, including major thoracic surgical procedures (thoracotomy, video-assisted thoracoscopic surgery
[VATS], median sternotomy, or mediastinoscopy) for noncancer outcomes. ${ }^{9}$ This concern has been inadequately addressed in the NELSON trial given no report on the number of PET/CTs, needle biopsies, and VATS was done in each of the study arms for a false positive result. This is vital in the context that real-world data have shown a higher false positive rate compared to the trial cohorts $(58.2 \%$ real-world vs $26.3 \%$ in NLST). ${ }^{10}$ The risk of radiation exposure from annual CT scans, albeit low dose, needs to be considered.

Lastly, $46.8 \%$ vs $7.1 \%$ of the lung cancers detected by screening were Stage I. Some may feel this is evidence of efficacy. Unfortunately, neither stage of diagnosis nor 5-year survival is a suitable metric to assess screening programs, as both are susceptible to lead and lengthen time bias. As such, mortality rates in a randomized population are the sole suitable metric for screening. 
In light of prior trials with no significant mortality benefit, and difficulties interpreting NLST due to a nonstandard control arm (CXR) and overall survival differences that are not fully accounted for by reductions in lung cancer-specific death, and which were no longer present in extended follow-up and subsequent publication, $^{2}$ the NELSON trial provides important clarity for LDCT screening. NELSON failed to show any suggestion of all-cause mortality benefit, and as such we believe further investigation is required to assess the full impact of lung cancer screening. As of 2020, in the process of shared decision-making with patients, we would suggest the following counseling: If you elect to undergo lung cancer screening, there is $13.93 \%$ risk of death at 10 years with screening and $13.76 \%$ risk of death without, and those percentages are statistically indistinguishable. As for the risk of lung cancer death, it is decreased from 3.2 to $2.4 \%$ with screening, a difference of $0.74 \%$. Communication of these facts is essential to informed decision-making.

Corresponding Author: Vinay Prasad, MD, MPH; Department of Epidemiology and Biostatistics, University of California, San Francisco, San Francisco, CA, USA (e-mail: vinayak.prasad@ucsf.edu).

\section{Declarations:}

Conflict of Interest: Vinay Prasad discloses the following: (research funding) Arnold Ventures; (royalties) Johns Hopkins Press, Medscape; (honoraria) grand rounds/lectures from universities, medical centers, non-profits, and professional societies; (consulting) UnitedHealthcare,
New Century Health; (speaking fees) Evicore; (other) Plenary Session podcast has Patreon backers.

Aakash Desai has nothing to disclose.

\section{REFERENCES}

1. Team NLSTR. Reduced lung-cancer mortality with low-dose computed tomographic screening. N Engl J Med. 2011;365(5):395-409.

2. National Lung Screening Trial Research Team. Lung Cancer Incidence and Mortality with Extended Follow-up in the National Lung Screening Trial. J Thorac Oncol. 2019;14(10):1732-1742.

3. Infante M, Cavuto $\mathbf{S}$, Lutman FR, et al. Long-term follow-up results of the DANTE trial, a randomized study of lung cancer screening with spiral computed tomography. Am J Respir Crit Care Med. 2015;191(10):11661175.

4. Paci E, Puliti D, Pegna AL, et al. Mortality, survival and incidence rates in the ITALUNG randomised lung cancer screening trial. Thorax. 2017;72(9):825-831

5. Becker N, Motsch E, Trotter A, et al. Lung cancer mortality reduction by LDCT screening - Results from the randomized German LUSI trial. Int J Cancer. 2019.

6. de Koning HJ, van der Aalst CM, de Jong PA, et al. Reduced LungCancer Mortality with Volume CT Screening in a Randomized Trial. N Engl J Med. 2020.

7. Chapa J. Interpreting the Effectiveness of Cancer Screening From National Population Statistics: Is It Sound Practice? Paper presented at: Mayo Clinic Proceedings2019.

8. Shaukat A, Mongin SJ, Geisser MS, et al. Long-term mortality after screening for colorectal cancer. N Engl J Med. 2013;369(12):1106-1114.

9. Wilson DO, Weissfeld JL, Fuhrman CR, et al. The Pittsburgh Lung Screening Study (PLuSS) outcomes within 3 years of a first computed tomography scan. Am J Respir Crit Care Med. 2008;178(9):956-961.

10. Caverly TJ, Fagerlin A, Wiener RS, et al. Comparison of Observed Harms and Expected Mortality Benefit for Persons in the Veterans Health Affairs Lung Cancer Screening Demonstration Project. JAMA Intern Med. 2018;178(3):426-428.

Publisher's Note Springer Nature remains neutral with regard to jurisdictional claims in published maps and institutional affiliations. 